\title{
The Control Mechanism of Sclerotial Formation in Sclerotium rolfsii Sacc.
}

\author{
By I. CHET AND Y. HENIS \\ Faculty of Agriculture, The Hebrew University of Jerusalem, Rehovot, Israel
}

(Accepted for publication I July I968)

\section{SUMMARY}

The distribution of $\left[{ }^{14} \mathrm{C}\right]-\mathrm{L}-c y s t e i n e$ and $\left[{ }^{14} \mathrm{C}\right]$ iodoacetic acid in mycelium and sclerotia of Sclerotium rolfsii Sacc., and the effect of disodium ethylenediaminetetraacetic acid ( $\left.\mathrm{Na}_{2} \mathrm{EDTA}\right)$, trans-I,2-diaminocyclohexane- $N, N$,$N^{\prime}, N^{\prime}$-tetraacetic acid (Chel. C.D.), potassium iodate and phenylthiourea on the formation of sclerotia by $S$. rolfsii were studied. $\left[{ }^{14} \mathrm{C}\right]$-labelled iodoacetic acid accumulated specifically in the sclerotia, whereas $\left[{ }^{14} \mathrm{C}\right]-\mathrm{L}$-cysteine was equally distributed throughout the mycelium. Accumulation of iodoacetic acid at specific sites was observed even before the formation of the sclerotia. Most of the radioactivity of the fungal mycelium grown on $\left[{ }^{14} \mathrm{C}\right]$ iodoacetic acid was found in the cell-free extract, $93 \%$ of the radioactivity of the extract being associated with the ammonium sulphate-precipitated fraction. $\mathrm{Na}_{2}-$ EDTA, Chel. C.D. and potassium iodate at $10^{-3} \mathrm{M}$ also induced sclerotial formation. The effect of $\mathrm{Na}_{2} \mathrm{EDTA}$ was eliminated by the addition of $3 \times \mathrm{IO}^{-5} \mathrm{M}_{-} \mathrm{Cu}^{2+}$, but not by $\mathrm{Fe}^{2+}, \mathrm{Zn}^{2+}, \mathrm{Co}^{2+}, \mathrm{Mn}^{2+}, \mathrm{Ca}^{2+}$ nor $\mathrm{Mg}^{2+}$. Phenylthiourea $\left(\mathrm{IO}^{-3} \mathrm{M}\right)$ initiated sclerotial formation but inhibited further development and melanogenesis. It is suggested that sclerotial formation in $S$. rolfsii is induced by inactivation of $\mathrm{a}-\mathrm{SH}+\mathrm{Cu}^{2+}$-containing protein entity which acts as a repressor of sclerotial formation.

\section{INTRODUCTION}

It was reported by Chet, Henis \& Mitchell (I966) that sclerotial production in Sclerotium rolfsii could be either prevented by L-cysteine or induced by iodoacetic acid, the compounds completely neutralizing each other at a molar ratio of $30: \mathrm{I}$. The high ratio required for this annulment might have resulted from differential cell permeability towards the compounds, or from differences in their distribution inside the hyphal cells. The site of action and target of these compounds might have been cell structures in which -SH groups are of significance, including the cell wall (Nickerson, I963), or enzymes involved in morphogenetic processes (Brachet, I964). Any working hypothesis which explains the effect of sulphur-containing amino acids and their antagonists on sclerotial formation in $S$. rolfsii must also include their distribution and binding sites inside the fungal cell as well as mechanical factors involved in sclerotial formation by $S$. rolfsii (Henis, Chet \& Avizohar-Hershenzon, 1965). Experiments made to investigate these problems, and a working hypothesis to explain the control mechanism of sclerotial formation in $S$. rolfsii, are presented in the present paper. 


\section{METHODS}

Organism. The Sclerotium rolfsii strain used in these experiments was isolated from sugar beet.

Radioautograms. Sclerotium rolfsii was grown on Petri dishes containing $15 \mathrm{ml}$. defined medium agar (Joham, I943), supplemented with $5 \mu \mathrm{c}$. of either $2-\left[{ }^{14} \mathrm{C}\right]$ iodoacetic acid (specific activity $35 \cdot 0 \mu \mathrm{c}$. $/ \mathrm{mg}$ ) or $3-\left[{ }^{14} \mathrm{C}\right]$-L-cysteine (specific activity $32 \cdot 0$ $\mu \mathrm{c} . / \mathrm{mg}$ ) obtained from The Radiochemical Centre, Amersham, Buckinghamshire, U.K. The final concentration of these compounds was adjusted to $10^{-4} \mathrm{M}$ and $1 \mathrm{IO}^{-2} \mathrm{M}$, respectively. Colonized agar discs, $0.5-1.5 \mathrm{~cm}$. in diameter, were used as inocula . The cultures were incubated for 15 days at $30^{\circ}$.

The agar medium was separated from the fungal colonies by melting the agar. The mycelial mats were washed with hot distilled water and dried in air on a glass cover of a Petri dish. A Kodak Medical X-ray film was then pressed firmly against the mycelium, and the whole placed in the dark for 5 days.

Distribution of radioactivity. Sclerotium rolfsii was grown in Petri dishes containing $15 \mathrm{ml}$. liquid defined medium supplemented with $5 \mu \mathrm{c}$. labelled iodoacetic acid or L-cysteine adjusted to $10^{-4} \mathrm{M}$ and $10^{-2} \mathrm{M}$, respectively, inoculated and incubated as described. Quantitative estimations of radioactivity were done with a Packard Tricarb Scintillation spectrometer model 3365 , using dried, thinly ground powder of either cell walls (Chet, Henis \& Mitchell, 1967), mycelium or sclerotia. Cell-free extracts were tested for radioactivity in a liquid form. Counts were calculated on a weight basis (dpm/mg. dry weight).

Preparation of cell-free extract. Sclerotium rolfsii was grown in a shallow layer of liquid defined medium (Joham, 1943) for Io days at $30^{\circ}$. Twenty g. (wet weight) of washed mycelium were taken in $20 \mathrm{ml}$. phosphate buffer $(\mathrm{M} / 40 ; \mathrm{pH} 6 \cdot 2)$, broken in a Waring Blendor for $10 \mathrm{~min}$. and treated in an MSE ultrasonic disintegrator for $5 \mathrm{~min}$. The remaining cells and cell debris were precipitated by centrifugation (12,000 $g$ for 10 min.) at $2^{\circ}$.

Protein determination. Protein content of the cell-free extract was determined by the Folin phenol method of Lowry, Rosebrough, Farr \& Randall (I95I).

Assay of cysteine reductase activity of the cell-free extract. This was done by following the oxidation of $\mathrm{NaDH}_{2}$ (A grade, Calbiochem, Lucerne, Switzerland) in a Shimadzu UV spectrophotometer, at $340 \mathrm{~m} \mu$ (Nickerson \& Romano, 1952).

\section{RESULTS}

Distribution of radioactivity in Sclerotium rolfsii grown on labelled iodoacetic acid or L-cysteine

Quantitative determinations of the radioactivity of various parts and fractions of Sclerotium rolfsii confirmed the results obtained with the radioautography technique (Table I). Whereas radioactivity of sclerotia and mycelium of $S$. rolfsii grown on $\left[{ }^{14} \mathrm{C}\right]-\mathrm{L}$-cysteine differed only slightly, radioactivity in colonies grown on $\left[{ }^{14} \mathrm{C}\right]$ iodoacetic acid accumulated specifically in the sclerotia. Radioautograms of colonies grown on agar medium supplemented with [I4C]-labelled iodoacetic acid showed a specific accumulation of radioactivity in the fungal sclerotia (Pl. I, fig. I, 2). Accumulation of radioactivity at specific sites was observed before any sclerotia were formed (PI. I, 
fig. 3,4$)$. The distribution of these sites on the fungal colony was very similar to that of sclerotia formed on an iodoacetate-supplemented medium. On the other hand, when the fungus was grown on media containing $1 \mathrm{IO}^{-2} \mathrm{M}-\mathrm{L}$-cysteine, radioactivity was distributed equally throughout the mycelium (PI. I, fig. 5, 6). When cell-free extract of fungal mycelium grown on $\left[{ }^{14} \mathrm{C}\right]$ iodoacetic acid was fully saturated with ammonium sulphate and centrifuged for $10 \mathrm{~min}$. at $\mathrm{I} 2,000 \mathrm{~g}, 93 \%$ of its radioactivity was found in the precipitate.

Table I. Distribution of radioactivity in mycelium and sclerotia of Sclerotium rolfsii grown in $\left[{ }^{14} \mathrm{C}\right]-\mathrm{L}$-cysteine or $\left[{ }^{14} \mathrm{C}\right]$ iodoacetic acid

$\begin{array}{cccc}\text { Compound added to growth medium } & \text { Tested form or fraction } & \begin{array}{c}\text { dpm/mg.* } \\ \text { dry weight }\end{array} & \begin{array}{c}\text { Standard error } \\ \text { of the mean }\end{array} \\ \text { Iodoacetic acid } 10^{-4} \mathbf{M} & \text { Sclerotia } & 365 & 7 \cdot 2 \\ & \text { Mycelium } & 153 & 6 \cdot 1 \\ \text { L-cysteine } 10^{-3} \mathbf{M} & \text { Sclerotia } & 216 & 6 \cdot 1 \\ \text { Iodoacetic acid } 10^{-4} \mathbf{M} & \text { Mycelium } & 182 & 7 \cdot \mathbf{I} \\ & \text { Cell-free extract } & 359 & 5 \cdot 3 \\ & \text { Hyphal cell walls } & 119 & 5 \cdot 1\end{array}$

* Each value represents the mean of four replicates.

\section{Effect of chelating agents on sclerotial formation}

The possibility was considered that sulphur-containing amino acids might have affected sclerotial formation through a chelating mechanism (Jones, 1964; MacLeod, Smith \& Gelinas, 1966). If so, other chelating agents might have a similar effect on sclerotium formation. Disodium ethylenediaminetetraacetic acid $\left(\mathrm{Na}_{2} \mathrm{EDTA}\right)$ and trans-I, 2-diaminocyclohexane- $N, N, N^{\prime}, N^{\prime}$-tetraacetic acid (Chel. C.D.) obtained from Fluka A.G., Switzerland, were added to the defined medium agar at final concentrations of $10^{-4}$ to ${ }^{10^{-2}} \mathrm{M}$. The agar plates were inoculated with Sclerotium rolfsii and incubated for Io days at $30^{\circ}$. The results are shown in P1. 2, fig. I, 2. As with iodoacetic acid, sclerotia were formed in concentric circles around the inoculum discs. However, they were unusually big, soft and light yellow in colour. They also fused into each other and formed irregularly shaped masses. Upon the addition of $\mathrm{Cu}^{2+}$ ions at $3 \cdot 10^{-5} \mathrm{M}$ to $10^{-2} \mathrm{M}-\mathrm{Na}_{2}$ EDTA-supplemented medium, sclerotial formation and appearance resembled the unsupplemented control (Pl. 2, fig. 3). Other ions ( $\mathrm{Fe}^{2+}$, $\mathrm{Mn}^{2+}, \mathrm{Zn}^{2+}, \mathrm{Mg}^{2+}, \mathrm{Co}^{2+}$ and $\mathrm{Ca}^{2+}$ at $\left.\mathrm{IO}^{-4}-\mathrm{IO}^{-2} \mathrm{M}\right)$ did not neutralize the effect of $\mathrm{Na}_{2}$ EDTA.

\section{Effect of phenylthiourea and potassium iodate on sclerotial formation}

Potassium iodate at $10^{-3} \mathrm{M}$ induced sclerotial formation in a way similar to that of iodoacetic acid, whereas phenylthiourea, a potent inhibitor of melanogenesis (Whittaker, 1966), induced the formation of sclerotial initials, but prevented their further development and maturation. However, colony growth was also strongly inhibited (P1. 2, fig. 4).

\section{'Cystine reductase' activity in Sclerotium rolfsii}

The presence of this enzymic activity of $S$. rolfsii is evident from Fig. I. 


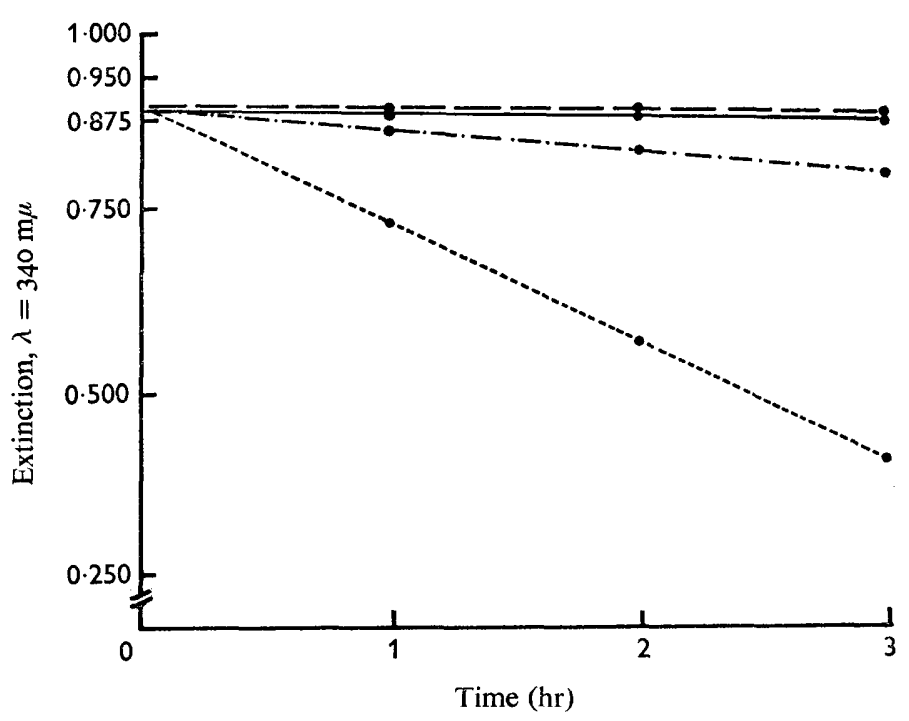

Fig. I. Cystine reductase activity of cell-free extract of Sclerotium rolfsii. Reaction mixture contained I ml. cell-free extract ( $500 \mu \mathrm{g}$. protein $/ \mathrm{ml}$.), $12 \mathrm{ml}$. phosphate buffer $(\mathrm{M} / 40, \mathrm{pH} 6 \cdot 2)$, I $\mathrm{ml}$. buffer solution saturated with cystine (0. I $2 \mathrm{mg} . / \mathrm{ml}$.). and $300 \mu \mathrm{g}$. $\mathrm{NADH}_{2}$. Boiled control was heated for $5 \mathrm{~min}$. at $100^{\circ}$. Reaction mixture was incubated in a Dubnoff shaking bath at $37^{\circ}$. Readings were made in a Shimadzu UV spectrophotometer at $340 \mathrm{~m} \mu$. --- , boiled extract + buffer $(\mathrm{pH} 6 \cdot 2) ;-\cdot-\cdot-, \mathrm{NADH}_{2}+$ extract + buffer;,$- \mathrm{NADH}_{2}+$ cystine + buffer; - - - -, $\mathrm{NADH}_{2}+$ cystine + extract + buffer, in a total volume of $\mathrm{I} 4 \mathrm{ml}$.

\section{DISCUSSION}

Radioautograms of Sclerotium rolfsii grown on $\left[{ }^{14} \mathrm{C}\right]$ iodoacetic acid showed a selective accumulation of radioactivity in the sclerotia. An increase in radioactivity at specific sites was observed in fungal colonies grown on iodoacetic acid before the initiation of sclerotial formation, these sites being distributed on the fungal colonies in a way similar to that of sclerotia on iodoacetate-grown colonies. In contrast to iodoacetic acid-grown cultures, radioactivity of colonies grown on $\left[{ }^{14} \mathrm{C}\right]-\mathrm{L}$-cysteine was equally distributed throughout the mycelium and in the few sclerotia which were formed. Thus, the relatively high concentrations of L-cysteine required to neutralize the effect of iodoacetic acid on S. rolfsii (Chet et al. 1966) may be partially explained by their different distribution in the fungal mycelium.

$\mathrm{Na}_{2}$ EDTA and potassium iodate induced sclerotial formation in concentric circles around the inoculum and induction by $\mathrm{Na}_{2}$ EDTA was completely prevented only by $\mathrm{Cu}^{2+}$. However, induction of sclerotial formation by potassium iodate may indicate that oxidation processes are also involved.

Felix \& Brouillet (I966) isolated -SH-containing peptidases from brewer's yeast; both enzymes were inhibited by $p$-chloromercuribenzoate and iodoacetate. However, only in one enzyme was the inhibition partially prevented by L-cysteine. This enzyme was not affected by EDTA. The other was EDTA-sensitive, $\mathrm{Ca}^{2+}$ and $\mathrm{Zn}^{2+}$ being effective in preventing the inhibitory effect of EDTA. Schramm (I964) showed the presence of masked -SH groups and calcium ions in pancreatic $\alpha$-amylase. Under normal conditions, amylase was not affected by iodoacetate, iodoacetamide and 
dithio-bis-2-nitrobenzoic acid (DTNB). Upon adding EDTA, some-SH groups became unmasked and reacted with DTNB and with $N$-methylimide, suggesting that masking of sulphydryl groups was mainly due to the tightening of the enzyme structure by bound calcium. On the basis of these observations, it is tempting to suggest that iodoacetic acid, chelating agents and potassium iodate induce sclerotial formation in Sclerotium rolfsii by modifying a sulphydryl-containing copper-linked protein entity which acts as a repressor of sclerotial formation; L-cysteine may decrease sclerotial formation by increasing its activity or its formation, or by slowing the rate of its turnover. Cystine can replace L-cysteine, being converted to the latter by 'cystine reductase' activity (Nickerson \& Romano, 1952) found in the mycelium of $S$. rolfsii. The formation of sclerotia in concentric circles, induced by iodoacetic acid, potassium iodate or $\mathrm{Na}_{2}$ EDTA, might have resulted from their specific accumulation, up to a critical concentration, at the growing hyphal tips of the fungal colony, causing the local inactivation of this hypothetical $-\mathrm{SH}+\mathrm{Cu}^{2+}$-containing repressor. The induction of sclerotial formation by mechanical means such as tearing or cutting (Henis et al. 1965) may also be explained by the inactivation of this repressor either by oxidation of -SH groups or by the accumulation of internal natural chelates such as organic acids as a result of nutrient flow to the damaged area. This explanation may also hold for the tendency of the fungus to produce sclerotia upon creating a contact with the side wall of the Petri dish. Such a contact temporarily arrests growth, and may result in the local increase of nutrients, flowing from the centre of the fungal colony toward its hyphal tips at the growing edge. It is believed that this working hypothesis will serve as a useful tool in further studies on the morphogenesis of $S$. rolfsii.

This work was supported by Grant No. FG-Is-I60 from the U.S. Department of Agriculture.

\section{REFERENCES}

BRACHET, J. (1964). The role of nucleic acids and sulphydryl groups in morphogenesis. Adv. Morphogenesis $3,247$.

Chet, I., Henis, Y. \& Mrtchell, R. (1966). The morphogenetic effect of sulphur-containing amino acids, glutathione and iodoacetic acid on Sclerotium rolfsii Sacc. J. gen. Microbiol. 45, 54I.

Chet, I., Henis, Y. \& Mitchell, R. (1967). Chemical composition of hyphal and sclerotial walls of Sclerotium rolfsii Sacc. Can. J. Microbiol. 13, 137.

Felix, F. \& Broulllet, N. (I966). Purification and properties of two peptidases from brewer's yeast. Biochim. biophys. Acta r22, 127.

Henis, Y., Chet, I. \& Avizohar-Hershenzon Z. (1965). Nutritional and mechanical factors involved in mycelial growth and production of sclerotia by Sclerotium rolfsii in artificial medium and amended soil. Phytopathology 55, 87.

JoHAM, H. E. (1943). A nutritional study on the fungus Sclerotium rolfsii. M.Sc. thesis, A and M College of Texas.

JONES, G. E. (1964). Effect of chelating agents on the growth of Escherichia coli in seawater. J. Bact. 87, 483 .

Lowry, O. H., Rosebrough, N. J., FARr, A. L. \& Randall, R. J. (I95I). Protein measurement with the Folin reagent. J. biol. Chem. 193, 265.

Macleod, R. A., Smith, L. D. H. \& Gelinas, R. (1966). Metabolic injury to bacteria. I. Effect of freezing and storage on the requirements of Aerobacter aerogenes and Escherichia coli for growth. Can. J. Microbiol. 12, 6I.

NiCKERSON, W. J. (1963). Symposium on biochemical basis of morphogenesis in fungi. IV. Molecular basis of form in yeasts. Bact. Rev. 27, 305. 
Nickerson, W. J. \& Romano, A. H. (I952). Enzymatic reduction of cystine by coenzyme I (DPNH). Science, N.Y. II5, 676.

SCHRAMm, M. (I964). Unmasking of sulphydryl groups in pancreatic $\alpha$-amylase. Biochemistry 3, I23I. WhITTAKER, J. R. (1966). An analysis of melanogenesis in differentiating pigment cells of Ascidian embryos. Devl. Biol. r4, I.

\section{EXPLANATION OF PLATES}

\section{Plate I}

Photographs (left) and corresponding radioautograms (right) of mycelial mats of Sclerotium rolfsii grown on a defined medium agar supplemented with $\left[{ }^{14} \mathrm{C}\right]-\mathrm{L}$-cysteine or $\left[{ }^{14} \mathrm{C}\right]$ iodoacetic acid.

Figs. 1 , 2. $\left[{ }^{14} \mathrm{C}\right]$ iodoacetic acid $\left(10^{-4} \mathrm{M}\right)$. Photographs taken after 15 days of incubation at $30^{\circ} .(\times 1$. Figs. 3, 4. As in fig. I and 2, after $24 \mathrm{hr}$. $(\times 4$.)

Figs. 5, 6. ${ }^{14} \mathrm{C}-\mathrm{L}$-cysteine $\left(10^{-2} \mathrm{M}\right)$. Photographs taken after $\mathrm{I} 5$ days of incubation at $30^{\circ} .(\times \mathrm{I}$.

\section{Plate 2}

Effect of chelating agents and phenylthiourea on sclerotia formation in Sclerotium rolfsii, after Io days at $30^{\circ}$.

Fig. I. $\mathrm{Na}_{2} \mathrm{EDTA} \mathrm{IO}^{-3} \mathrm{M}(\times \mathrm{I}$.

Fig. 2. Trans-I,2-diaminocyclophexane- $N, N, N^{\prime}, N^{\prime}$-tetraacetic acid $10^{-3} \mathrm{M}$. $(\times$ I.)

Fig. 3. Control. $(\times I$.)

Fig. 4. Phenylthiourea $1 \mathrm{O}^{-3} \mathrm{M}$. (I.) 
Journal of General Microbiology, Vol. 54, No. 2

Plate I
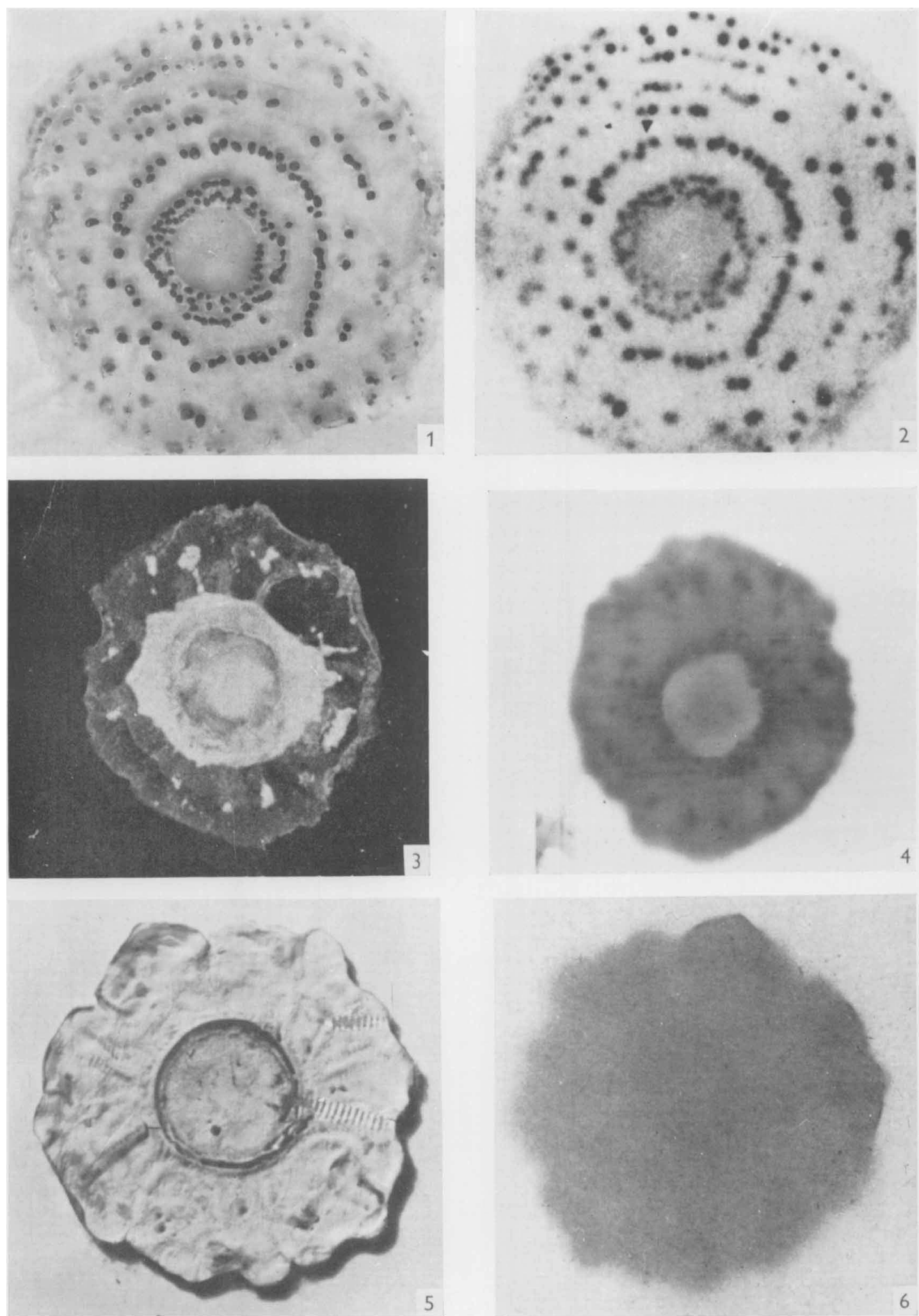
Journal of General Microbiology, Vol. 54, No. 2

Plate 2
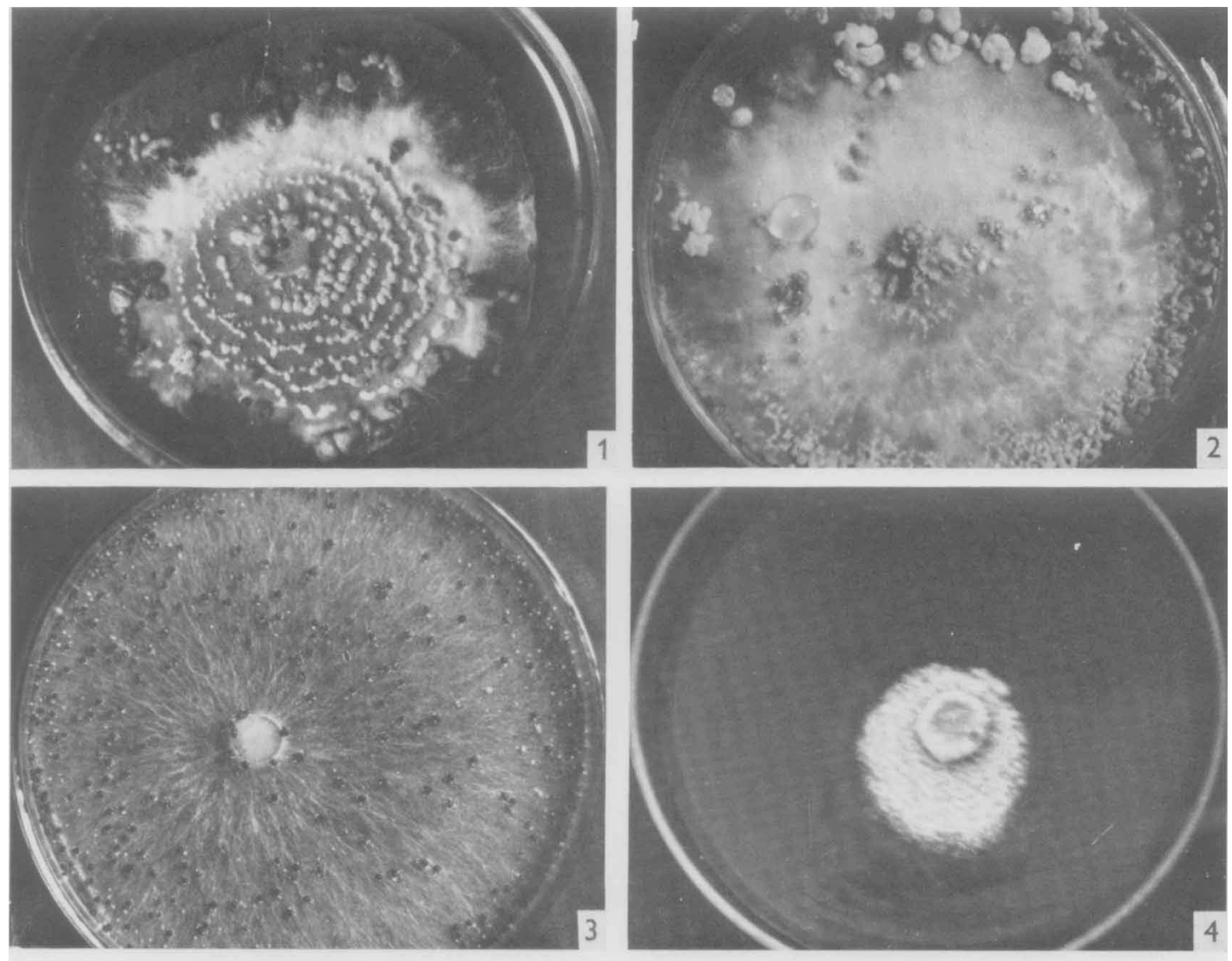